\title{
What do people think about technological enhancements of human beings? An introductory study using the Technological Enhancements Questionnaire in the context of values, the scientistic worldview, and the accepted versions of humanism
}

\author{
Daniel Stefański $i^{A, B, D, E, F}$, Łukasz fach (ID) ${ }^{A, C, D, E, F}$
}

University of Silesia, Katowice, Poland

\section{BACKGROUND}

Rapid development of technologies increases the possibility of technological enhancements of human beings, e.g., in their cognitive skills or physical fitness. Attitudes towards such enhancements may result in their social acceptance or rejection.

\section{PARTICIPANTS AND PROCEDURE}

One hundred and thirty-nine young Polish adults participated in the study. Participants completed the designed Technological Enhancements Questionnaire (TEQ) and questionnaires to measure values, the scientistic worldview, and the accepted versions of humanism.

\section{RESULTS}

The study showed a one-dimensional TEQ structure and its satisfactory reliability. Attitudes towards technologi- cal enhancements correlated positively with achievement, self-direction in thought, power over resources, the scientistic worldview, and the evolutionary version of humanism. They also correlated negatively with tradition and the liberal version of humanism.

\section{CONCLUSIONS}

The TEQ questionnaire is a short, reliable tool to measure attitudes towards technological enhancements. This preliminary study provided some significant results, but future work to validate the questionnaire is needed.

\section{KEY WORDS}

values; scientistic worldview; transhumanism; versions of humanism; technological enhancements

CORResPonding AUthor - Łukasz Jach, Ph.D., University of Silesia, 53 Grażyńskiego Str., 40-126 Katowice, Poland, e-mail: lukasz.jach@us.edu.pl

Authors' Contribution - A: Study design - B: Data collection - C: Statistical analysis - D: Data interpretation .

E: Manuscript preparation · F: Literature search · G: Funds collection

to Cite this ARTICLE - Stefański, D., \& Jach, Ł. (2022). What do people think about technological enhancements of human beings? An introductory study using the Technological Enhancements Questionnaire in the context of values, the scientistic worldview, and the accepted versions of humanism. Current Issues in Personality Psychology, 10(1), 71-84. 
What do people think about technological enhancements...

\section{BACKGROUND}

Due to scientific discoveries and the rapid development of technologies, the borders between science fiction and reality are currently blurring (Harari, 2015). This phenomenon manifests itself in the possibility of technological enhancements of human beings, for example, in their cognitive skills, physical fitness, and endurance (Whitman et al., 2018). Human enhancement may be defined as a modification aimed at improving individual human performance and brought about by science-based or technologybased interventions in the human body (Coenen et al., 2008). Enhancing human beings has a long history, and its traditional forms are education (e.g., mnemotechnics), training (e.g., martial arts), and the use of natural substances such as caffeine (Bostrom \& Sandberg, 2009). Examples of the therapeutic use of technology are prostheses and devices such as glasses, hearing aids, and cochlear implants, designed to bring people's functioning to a level which is characteristic for the majority of the population (Bates at al., 2020; Daniels, 2000).

However, the distinction between therapeutic use and enhancements may be difficult to define (Erler, 2017), and the same technologies can serve both reducing deficits and increasing a given feature above the level typical for the human population (e.g., nootropic drugs which may enhance cognitive skills; see: Chadwick, 2008; Fahn, 2020; Whetstine, 2015).

In the future, implementations of human enhancements are foreseen, using advanced cybernetic, genetic, engineering, and pharmacological technologies (Jotterand, 2010; Lilley, 2013; Whitman et al., 2018). In this context, Pirmagomedov and Koucheryavy (2019) distinguish between three types of augmentation: physical, sensory, and mental. Examples of physical enhancements are exoskeletons and artificial arms and legs (Pirmagomedov \& Koucheryavy, 2019). Sensory enhancements, such as infrared vision or sensing an electromagnetic field, may allow people to perceive naturally unperceived stimuli (Barfield \& Williams, 2017). Mental enhancements may act, for example, by stimulating or weakening brain regions related to memory, emotions, or decision making (Barfield \& Williams, 2017; Pirmagomedov \& Koucheryavy, 2019). Currently, the issue of technological enhancement is discussed, e.g., in the context of developing brain-machine interface technology. On the one hand, it is presented as a method of restoration of sensory and motor function and the treatment of neurological disorders (Musk \& Neuralink, 2019), and on the other hand, as a technology that may be used for mind and behavior control and to change the cultural concepts of privacy, autonomy, and self (Gurtner, 2021; Nakar et al., 2015).

According to Harari $(2015,2017)$, the technological enhancement of human beings seems to be an inevitable direction of the development of humanity. However, such enhancements may be assessed differently from the perspective of different versions of cultural narratives about human nature, traits, and destiny. Harari (2017) points out that three main types of definitions of humanism have emerged in the history of humanity. Liberal humanism emphasizes the freedom and uniqueness of the individual. In this version of humanism, every person is valuable, and the world is better when the more freely individual people can fulfill themselves following their preferences. Social humanism emphasizes groups and collectives. According to this version of humanism, the perspective of individuals is less important, people should associate and act for the good of communities, and collective needs should be more important than personal needs. Evolutionary humanism posits objective differences between people and recognizes that conflict is the basis of development. This version of humanism is related to the belief that humanity should develop at the species level, leading through systematic improvement and overcoming difficulties to the emergence of the "superhuman" species.

Technological enhancements of human beings are endorsed from the transhumanist perspective, which postulates the crossing of human biological limitations thanks to advanced technologies (Klichowski, 2015; Lilley, 2013). Kurzweil (2006) believes that thanks to technological enhancements of human beings, people will finally have the opportunity to fulfill their eternal desires for an endless, disease-free, and suffering-free life in happiness. From a different perspective, technological enhancements also raise several concerns. Tegmark (2017) shows that the close connection of biological aspects with technological and cybernetic inventions can result in various scenarios for the future of humanity. Schelle et al. (2014) indicate that social concerns about cognitive enhancements using pharmacological technologies raise three main issues: medical safety, coercion, and fairness. The safety aspect relates to the difficulty of predicting the long-term consequences of enhancements and the balance between personal benefits and costs. Coercion refers to possible environmental pressures forcing people to use enhancements to increase their effectiveness or social utility. The fairness aspect relates to the possibility of establishing or strengthening social inequalities through differences in access to enhancing technologies.

\section{AIMS OF THE STUDY}

Regardless of the actual possibility of the widespread use of technological enhancements in the foreseeable future, from a psychological point of view, an 
interesting issue is the study of people's attitudes towards such enhancements that may result in their social acceptance or rejection. The aim of this study was to prepare a questionnaire for measuring attitudes towards technological enhancements of human beings.

Another goal was to conduct preliminary research on its validity. For this purpose, we measured the relationships between attitudes towards technological enhancements of human beings and issues related to such aspects as personal values (Cieciuch \& Schwartz, 2018) and beliefs about the role of science in the contemporary world (Jach, 2019, 2021). Additionally, we measured the relationship between attitudes towards technological enhancements of human beings and the level of acceptance for various versions of humanism indicated by Harari (2017).

According to Schwartz (1992), values are transsituational goals, varying in importance, that serve as guiding principles in the life of a person or a group. The latest conceptualization of Schwartz's model includes 19 values organized in a circular structure in which the coherent values are next to each other, and the divergent values are placed opposite each other (Cieciuch \& Schwartz, 2018). An analysis of the transhumanist postulates (Bostrom, 2005; Klichowski, 2015) leads to the conclusion that technological enhancements are consistent with self-enhancement values such as achievement and power over resources. From a different perspective, the concerns about fairness, coercion, and medical safety indicated by Schelle et al. (2014) lead to the hypothesis about negative relationships between attitudes towards technological enhancements of human beings and the values of safety and universalism. Radical changes introduced to human life due to technological enhancements may also be inconsistent with traditional values (Lilley, 2013).

According to Jach $(2019,2021)$, the contemporary development of science and technology has led to the dissemination of the scientistic worldview, which can be defined as a form of worldview characterized by the tendency to justify one's beliefs and behavior with scientific findings and to function based on theorems formulated by scientists. The scientistic worldview components are: trust in the scientific method, recognizing scientists as the only valuable experts, hoping that science will completely overcome problems that arise in human life, and considering science the best tool for exerting a practical influence on reality. A high level of trust in science and technological solutions is a common element of the scientistic worldview and transhumanist postulates. For this reason, a hypothesis can be made about the positive relationships of the mentioned worldview and attitudes towards technological enhancements of human beings.
Although all three visions of humanism mentioned by Harari (2017) are very different from each other, they still constitute the context of the life of contemporary people. While Harari describes the types of humanism as cultural perspectives, it seems reasonable to assume that these types of humanism will also be reflected in personal worldviews. From this perspective, it can be assumed that attitudes towards technological enhancements of human beings will be positively related to evolutionary humanism (emphasizing the importance of development and improvement) and negatively related to liberal (emphasizing the importance of freedom from coercion) and social humanism (emphasizing the importance of fairness and equal opportunities for all people).

\section{PARTICIPANTS AND PROCEDURE}

\section{PARTICIPANTS}

Due to the very recent characteristic of the research topic and its close relation to developing the new technologies, the study was conducted among young adults. Questionnaires were distributed among the respondents using the snowball sampling method. Participants could complete questionnaires in "paper and pencil" form or as an online survey. Participation in the study was anonymous and voluntary.

One hundred and thirty-nine Polish respondents (83 female and 53 male) participated in the study. The age of the participants was between 19 and 40 $(M=23.97, S D=4.36)$. Among the surveyed participants, $2(1.44 \%)$ had vocational education, $98(70.50 \%)$ had a secondary level of education, and 39 (28.06\%) had a higher level of education. Male and female participants did not differ in terms of age $(t(137)=.66$, $p=.512)$ or level of education $\left(\chi^{2}(2)=1.75, p=.418\right)$.

\section{PROCEDURE}

Participants were first introduced to a brief description of technological enhancements of human beings and then completed the provided set of questionnaires. The definition of technological enhancements of human beings was presented to participants twice; for the first time in the introductory part of the survey ("The study concerns the relationship of psychological aspects with an attitude towards technological enhancements of human beings, that is, all forms of technological influences on people in order to increase their physical or mental capabilities") and for the second time in the instruction to the Technological Enhancements Questionnaire ("Technological enhancements of human beings are all technical measures by which their users' physical and mental abilities can be increased"). 


\section{MEASURES}

The Technological Enhancements Questionnaire (TEQ) was developed to measure attitudes towards technological enhancements of human beings (see Appendix A). The tool consists of 14 statements, each with five possible answers $(1-$ definitely disagree, 2 - mostly disagree, 3 - partially agree and partially disagree, 4 - mostly agree, 5 - definitely agree). For some items, the scoring is reversed. The content of the statements relates to such issues as the acceptance of the development of the technological enhancements, the readiness to use the technological enhancements, and the hopes and concerns related to them. The set of items included in the TEQ questionnaire was selected from a more extensive set of statements according to the opinions given by a group of judges familiarized with the concept of technological enhancements of human beings.

The Versions of Humanism Questionnaire. To study attitudes towards different versions of humanism, the Versions of Humanism Questionnaire was developed (see Appendix B). The questionnaire was developed based on Harari's (2017) concept, distinguishing three versions of humanism: liberal, social and evolutionary. The tool consists of 25 items related to modern people's life, for example, education, social life, art, and the role of the state. For each of them, the respondents choose one answer that best suits their views. The results are the sums of responses related to the liberal, social, and evolutionary version of humanism. The higher the score related to a given version of humanism, the more this version of humanism is accepted by the respondent. The set of items included in the questionnaire refers to the essential spheres of human life indicated by a group of judges familiarized with the concept of the three versions of humanism proposed by Harari (2017). The possible answers have been designed to reflect the differences between these three versions of humanism as accurately as possible.

The Views of Science Questionnaire (VoSQ; Jach, $2019,2021)$ was used to measure attitudes towards the meaning of the scientific context in the contemporary world. The tool consists of 16 statements, each with five possible answers. The sum of the points obtained in all items is a score referring to a scientistic worldview level. The items relate to such issues as trust in the scientific method, perceiving scientists as the only experts, hoping for science to radically improve the condition of humanity, and considering science as a tool of practical influence on the surrounding world. Studies conducted so far have shown that scientistic worldview correlates positively with attitudes towards vaccines (Jach, 2020), esthetic evaluation of graphics depicting objects of scientific research (e.g., galaxies, neurons, fractals; Jach, 2020), and the perceived level of credibility of advertisements containing scientific references (Jach \& Chmiel, 2018). Moreover, a study conducted by Jach and Buczek (2021) showed that the higher the scientistic worldview is, the greater is the acceptance of violation of ethical norms due to scientific development. The reliability of the VoSQ questionnaire in the present study was satisfactory (all Cronbach's $\alpha$ coefficients are included in Table 1).

The revised Portrait Values Questionnaire (PVQ-RR). Participants' values were measured using the PVQRR questionnaire (Cieciuch \& Schwartz, 2018). The questionnaire consists of 57 items, corresponding to 19 values: achievement, hedonism, stimulation, self-direction in action, self-direction in thought, universalism-tolerance, universalism-nature, universalism-concern, benevolence-caring, benevolencedependability, humility, conformity-interpersonal, conformity-rules, tradition, security-societal, security-personal, face, power-resources, and power-dominance). The higher the score on each scale, the more appreciated the given value is. The values identified in the model used are characterized by a satisfactory level of intercultural universality (Cieciuch et al., 2014) and are positively related to behaviors relevant to their daily fulfillment (Schwartz et al., 2017).

All presented statistical analyses were performed using JASP 0.14.1.0 software or Statistica 13 software.

\section{RESULTS}

\section{STRUCTURE AND RELIABILITY OF THE TECHNOLOGICAL ENHANCEMENTS QUESTIONNAIRE}

The frequencies of responses to each item are shown in Table A in Appendix C. Bartlett's test and the Kaiser-Meyer-Olkin test were carried out to check whether the data collected using the TEQ questionnaire are suitable to use factor analysis. The results of both tests indicated the validity of the factor analysis: Bartlett's test $\chi^{2}(98)=1038.80, p<.001 ; \mathrm{KMO}$ test value $=.914$. Confirmatory factor analysis using varimax rotation revealed one factor with an eigenvalue above 1 (eigenvalue $=6.40 ; 45.7 \%$ of variance explained). The factor loadings ranged between .460 and $.855($ mean $=.666)$.

Subsequently, the reliability of the identified scale was analyzed: the standardized Cronbach's $\alpha$ coefficient was .92, the mean item-item correlation coefficient was .45 , and the mean item-scale correlation coefficient was .64 (for more information on the item-scale correlation coefficients, see Table A in Appendix C). The obtained results allow the TEQ questionnaire to be considered as a reliable tool to measure attitudes towards technological enhancements of human beings. 


\section{DESCRIPTIVE STATISTICS OF MEASURED VARIABLES}

Table 1 presents data on the descriptive statistics of the studied variables, their reliability, and distribution.
Since among all measured variables, only the results concerning attitudes towards technological enhancements of human beings and the scientistic worldview were characterized by a distribution close to normal, non-parametric tests were used in further analyses.

Table 1

Descriptive statistics and reliability of variables measured

\begin{tabular}{|c|c|c|c|c|c|c|c|c|}
\hline Variable & $M$ & $S D$ & Min & Max & Skewness & Kurtosis & $\begin{array}{c}\text { Shapiro- } \\
\text { Wilk W test } \\
p \text {-value }\end{array}$ & $\begin{array}{c}\text { Cronbach's } \alpha \\
\text { coefficient }\end{array}$ \\
\hline $\begin{array}{l}\text { Attitudes towards } \\
\text { technological } \\
\text { enhancements } \\
\text { of human beings }\end{array}$ & 49.73 & 10.41 & 19 & 70 & -0.29 & -0.36 & .108 & .92 \\
\hline Scientistic worldview & 49.34 & 12.17 & 20 & 80 & -0.03 & -0.14 & .596 & .89 \\
\hline Achievement & 13.05 & 3.33 & 3 & 18 & -0.58 & 0.00 & $<.001$ & .82 \\
\hline Hedonism & 14.21 & 2.43 & 7 & 18 & -0.50 & -0.05 & $<.001$ & .69 \\
\hline Stimulation & 10.94 & 3.56 & 4 & 18 & -0.14 & -0.82 & .006 & .76 \\
\hline $\begin{array}{l}\text { Self-direction } \\
\text { in action }\end{array}$ & 15.21 & 2.26 & 6 & 18 & -0.83 & 0.98 & $<.001$ & .79 \\
\hline $\begin{array}{l}\text { Self-direction } \\
\text { in thought }\end{array}$ & 15.25 & 2.20 & 9 & 18 & -0.68 & 0.02 & $<.001$ & .74 \\
\hline $\begin{array}{l}\text { Universalism- } \\
\text { tolerance }\end{array}$ & 14.47 & 2.59 & 6 & 18 & -0.89 & 0.67 & $<.001$ & .73 \\
\hline Universalism-nature & 13.59 & 3.18 & 5 & 18 & -0.71 & 0.02 & $<.001$ & .88 \\
\hline Universalism-concern & 14.37 & 3.01 & 5 & 18 & -0.85 & 0.27 & $<.001$ & .76 \\
\hline Benevolence-caring & 15.22 & 2.30 & 7 & 18 & -0.96 & 0.83 & $<.001$ & .78 \\
\hline $\begin{array}{l}\text { Benevolence- } \\
\text { dependability }\end{array}$ & 15.45 & 2.33 & 5 & 18 & -1.07 & 1.96 & .003 & .76 \\
\hline Humility & 11.01 & 3.03 & 3 & 18 & -0.32 & -0.22 & .039 & .51 \\
\hline $\begin{array}{l}\text { Conformity- } \\
\text { interpersonal }\end{array}$ & 11.09 & 3.86 & 3 & 18 & -0.05 & -0.96 & $<.001$ & .89 \\
\hline Conformity-rules & 11.22 & 3.66 & 3 & 18 & -0.20 & -0.60 & .014 & .87 \\
\hline Tradition & 10.14 & 4.23 & 3 & 18 & -0.02 & -1.10 & $<.001$ & .88 \\
\hline Security-societal & 14.35 & 3.20 & 3 & 18 & -1.00 & 0.89 & $<.001$ & .88 \\
\hline Security-personal & 13.55 & 2.63 & 6 & 18 & -0.32 & -0.46 & .002 & .66 \\
\hline Face & 13.22 & 2.99 & 3 & 18 & -0.86 & 0.95 & $<.001$ & .75 \\
\hline Power-resources & 9.75 & 3.53 & 3 & 18 & 0.14 & -0.52 & .045 & .82 \\
\hline Power-dominance & 7.27 & 3.19 & 3 & 18 & 1.04 & 1.26 & $<.001$ & .84 \\
\hline Liberal humanism (103) & 12.43 & 3.23 & 5 & 19 & -0.15 & -0.51 & .033 & not applicable \\
\hline Social humanism (19) & 7.91 & 2.55 & 1 & 15 & 0.13 & 0.11 & .010 & not applicable \\
\hline $\begin{array}{l}\text { Evolutionary } \\
\text { humanism (8) }\end{array}$ & 4.66 & 3.06 & 0 & 17 & 1.05 & 1.32 & $<.001$ & not applicable \\
\hline
\end{tabular}

Note. In versions of humanism, it is indicated in brackets for how many respondents a given version of humanism was dominant. 


\section{ATTITUDES TOWARDS TECHNOLOGICAL ENHANCEMENTS OF HUMAN BEINGS AND DEMOGRAPHIC CHARACTERISTICS OF THE SAMPLE}

The male participants $(M=52.11, S D=10.03)$ had more positive attitudes towards technological enhancements of human beings than the female participants $(M=48.13, S D=10.41): t(137)=2.24, p=.027$, Cohen's $d=.39$. Respondents' attitudes towards technological enhancements of human beings were not related to their age: $r=-.12, p=.162$. The level of education of the participants was not related to attitudes towards technological enhancements of human beings: $t(135)=.70, p=.486$ (participants with vocational education were not included in this comparison due to the small number)

\section{CORRELATES OF ATTITUDES TOWARDS TECHNOLOGICAL ENHANCEMENTS OF HUMAN BEINGS}

The relationships between the attitudes towards technological enhancements of human beings and the scientistic worldview, values, and versions of humanism were measured using Spearman's rho coefficients. The results of the analysis are shown in Table 2.

Attitudes towards technological enhancements of human beings were positively associated with the scientistic worldview and the evolutionary version of humanism. Lower positive relationships were also noted concerning such values as achievement, self-direction in thought, and power over resources. Negative relationships linked attitudes towards technological enhancements of human beings with the value of tradition and the liberal version of humanism.

\section{DISCUSSION}

The obtained results allow the TEQ to be considered as a reliable, one-dimensional tool for measuring attitudes towards technological enhancements of human beings. However, the analysis of the frequency of responses to individual items of the TEQ questionnaire motivates searching for its better internal structure. For example, in items 3,8 , and 11 , the respondents

Table 2

Attitudes towards technological enhancements of human beings and other measured variables - Spearman's rho correlation coefficient values

\begin{tabular}{|c|c|c|c|c|c|}
\hline $\begin{array}{l}\text { Significant } \\
\text { correlations }\end{array}$ & $\begin{array}{c}\text { Attitudes } \\
\text { towards } \\
\text { technological } \\
\text { enhancements } \\
\text { of human } \\
\text { beings }\end{array}$ & $\begin{array}{c}\text { Non-significant } \\
\text { correlations }\end{array}$ & $\begin{array}{c}\text { Attitudes } \\
\text { towards } \\
\text { technological } \\
\text { enhancements } \\
\text { of human } \\
\text { beings }\end{array}$ & $\begin{array}{c}\text { Non-significant } \\
\text { correlations }\end{array}$ & $\begin{array}{c}\text { Attitudes } \\
\text { toward } \\
\text { technological } \\
\text { enhancements } \\
\text { of human } \\
\text { beings }\end{array}$ \\
\hline $\begin{array}{l}\text { Scientistic } \\
\text { worldview }\end{array}$ & $.51^{* * *}$ & Stimulation & .06 & $\begin{array}{l}\text { Conformity- } \\
\text { interpersonal }\end{array}$ & .02 \\
\hline Achievement & $.17^{*}$ & $\begin{array}{l}\text { Self-direction } \\
\text { in action }\end{array}$ & .13 & $\begin{array}{l}\text { Conformity- } \\
\text { rules }\end{array}$ & -.14 \\
\hline $\begin{array}{l}\text { Self-direction } \\
\text { in thought }\end{array}$ & $.18^{*}$ & $\begin{array}{l}\text { Universalism- } \\
\text { tolerance }\end{array}$ & -.07 & $\begin{array}{l}\text { Security- } \\
\text { societal }\end{array}$ & .02 \\
\hline Tradition & $-.31^{* * *}$ & $\begin{array}{l}\text { Universalism- } \\
\text { nature }\end{array}$ & .01 & $\begin{array}{l}\text { Security- } \\
\text { personal }\end{array}$ & -.10 \\
\hline $\begin{array}{l}\text { Power- } \\
\text { resources }\end{array}$ & $.18^{*}$ & $\begin{array}{l}\text { Universalism- } \\
\text { concern }\end{array}$ & -.14 & Face & .15 \\
\hline $\begin{array}{l}\text { Liberal } \\
\text { humanism }\end{array}$ & $-.28^{* *}$ & $\begin{array}{l}\text { Benevolence- } \\
\text { caring }\end{array}$ & -.02 & $\begin{array}{c}\text { Power- } \\
\text { dominance }\end{array}$ & .00 \\
\hline \multirow[t]{2}{*}{$\begin{array}{l}\text { Evolutionary } \\
\text { humanism }\end{array}$} & $.42^{* * *}$ & $\begin{array}{l}\text { Benevolence- } \\
\text { dependability }\end{array}$ & .09 & $\begin{array}{c}\text { Social } \\
\text { humanism }\end{array}$ & -.15 \\
\hline & & Humility & -.11 & Hedonism & .16 \\
\hline
\end{tabular}


presented very little differentiation of responses (e.g., in item 11, only two people chose one of the possible negative responses). In future works, consideration may be given to shortening the TEC questionnaire by removing these relatively weakly differentiating items, especially since even in the current study, their removal did not reduce the reliability of the questionnaire (see Table A in Appendix C).

The relationships between the attitudes towards technological enhancements of human beings and the values indicated in Schwartz's circular model of values were partially consistent with the hypotheses. Attitudes towards technological enhancements of human beings were significantly positively related to the values of achievement, self-direction in thought, and power over resources. These results suggest that the transhumanist postulates of technological enhancements may be more favored by those focused on independence, personal success, and using all available opportunities.

Attitudes towards technological enhancements of human beings were negatively related only to the value of tradition. This result can be explained by the anticipated radical changes that technological enhancements may bring in the socio-cultural sphere. People who respect tradition may find it difficult to accept the need to redefine many of the concepts that have so far been appreciated. The negative relationship between attitudes towards technological enhancements and tradition is also consistent with the circular model of value (Cieciuch \& Schwartz, 2018; Schwartz et al., 2017), where the value of tradition stands in opposition to those values which in the current study correlated positively with attitudes towards technological enhancements: achievement, and self-direction in thought.

From a different perspective, most of the analyzed values did not correlate significantly with attitudes towards technological enhancements. These results may indicate a vague understanding of this issue and difficulties in visualizing its more general consequences of technological enhancement of human beings. However, relatively weak relationships of attitudes towards technological enhancements of human beings with values may also indicate that the values do not constitute a crucial context for potential human responses to the manifestation of such enhancements. This finding is a source of motivation to look for other psychological variables that may be more important from the point of view of attitudes towards technological enhancements.

The obtained results on the relationship between attitudes towards technological enhancements of human beings and values can also be compared with the declarative transhumanist values. According to Bostrom (2005), the core transhumanist value is having the opportunity to explore possibilities given by technological development, and derived values in- clude individual choice, improving understanding, getting smarter, pacifism, pragmatism, caring about wellbeing, possibility to "tamper with nature" and acceptance of any form of diversity. On the conceptual level, the mentioned values seem to be in accordance with such values of Schwartz as universalism, selfdirection, stimulation, and achievement, and in opposition to such values as tradition, conformity, and power. Some results obtained in the current research support the idea that conceptual values of transhumanism correspond with personal values related to attitudes towards technological enhancements of human beings. However, the current study did not reveal correlations of mentioned attitudes with universalism, stimulation, and conformity, suggesting that the psychological background of attitudes towards technological enhancements may be different from the perspective presented in transhumanist manifests.

The positive relationships of attitudes towards technological enhancements of human beings with the scientistic worldview indicated in the hypothesis were significant and the strongest of all measured relationships. This result suggests that people who trust scientists and the scientific way of describing phenomena may be more favorable to technological enhancements of human beings. From a different perspective, the obtained result leads to the conclusion that the large-scale development of the scientistic worldview may constitute the basis for future acceptance for the implementation of technological enhancements in human beings. In this context, the scientistic worldview may underlie the support for the acceptance of technological enhancements.

In line with the hypothesis, attitudes towards technological enhancements were positively associated with the evolutionary version of humanism and negatively with the liberal version of humanism. The positive correlation with the evolutionary version of humanism suggests that more positive attitudes towards technological enhancements may be associated with perceiving society as composed of people with various predispositions that can be assessed as "better" and "worse". On the other hand, a negative correlation with the liberal version of humanism indicates that less positive attitudes towards technological enhancements may accompany the belief that every human being should be able to make independent choices and the belief that it is difficult to make a detailed evaluation of specific properties (e.g., cognitive).

However, there were no significant relationships between attitudes towards technological enhancements and social humanism, although the direction of the relationship was consistent with the hypothesis. These results could be related to the relatively small sample size, although the obtained results can also be interpreted in terms of ambiguity of opportunities and threats related to collective fairness postulates. On the one hand, in a situation of unequal 
What do people think about technological enhancements...

access to technological enhancements, they may perpetuate interpersonal divisions, but in a situation of broad and equal access, they may lead to greater compliance with the perspective of social humanism. Recent international studies on public views of human enhancement technologies (Prudhomme et al., 2020) have shown that the most common is an egalitarian approach to the availability of technological enhancements.

\section{LIMITATIONS}

The most important limitation of the current study is related to the research sample - relatively small and collected using the snowball sampling method. Although this preliminary study showed good reliability and a unidimensional structure of the TEQ questionnaire, the psychometric parameters of the mentioned questionnaire should be measured in more extensive and more representative samples of respondents. Another limitation related to the sample is that only young adults were included in the study. On the one hand, the sample structure made it possible to interpret the obtained results in isolation from developmental aspects; but on the other hand, this structure made a more general interpretation of the results impossible. Future research using TEQ should include more demographically diverse samples.

Another significant limitation of the present study is the inclusion of a relatively small number of variables that can be considered indicators of the validity of the TEQ questionnaire. Although positive correlations with the scientistic worldview and several relationships with values (predominantly negative relationships with tradition) suggest that the tool measures attitudes towards technological enhancements of human beings, future research should include a more detailed study of the validity of the TEQ questionnaire.

\section{FUTURE RESEARCH DIRECTIONS}

As mentioned above, the primary direction of future research using the TEQ should include repeating the present study in a larger sample. Future research may also include more differentiated psychological variables, which may be related to attitudes towards technological enhancements of human beings, especially due to the relatively weak relationships of such attitudes with values. In this context, it seems interesting to include research on psychological wellbeing (e.g., Karaś \& Cieciuch, 2017; Ryff, 1989), people's perception of the functions of health (Górnik-Durose et al., 2020), and the functions of their bodies (e.g., Barreto et al., 2011). It could also be interesting to measure the relationship between attitudes towards technological enhancements of human beings and aspects related to moral dimensions (Haidt \& Joseph, 2007). The issues presented in the article can also be significantly developed through a more detailed examination of concerns about technological enhancements related to security, coercion, and fairness (Schelle et al., 2014).

\section{CONCLUSIONS}

The results of contemporary scientific research and technological development may lead to technological enhancements of human beings becoming a common phenomenon. Psychological research related to this issue can provide knowledge about variables related to accepting or rejecting technological enhancements. Such knowledge may soon be essential due to the possible impact of technological enhancements of human beings, e.g., in the spheres of work (Whitman et al., 2018), health (Academy of Medical Sciences, 2012), warfare (Latheef \& Henschke, 2020), and education (Tilson \& Aldridge, 2018), as well as its possible political (Blotget-Ford, 2021) and social (Lilley, 2013) consequences.

According to Jensen et al. (2020), Polish research on aspects related to human enhancements is at the very initial stage. However, the report of Prudhomme et al. (2020) showed that the majority of Poles surveyed would support technology that would extend human life to 120 years, increase the level of human intelligence, increase the level of morality and provide control over emotions.

In the context of the results of the above reports, it seems that a psychological tool is needed to study attitudes towards technological enhancements of human beings. The TEQ questionnaire presented in the article can be used as a short, reliable tool for researching the issues mentioned above. While this preliminary study identified several relationships between attitudes towards technological enhancements and such psychological aspects as values, scientistic worldview, and versions of humanism, future work on validating the questionnaire is needed.

\section{REFERENCES}

Academy of Medical Sciences (2012). Human enhancement and the future of work. Report from a joint workshop hosted by the Academy of Medical Sciences, the British Academy, the Royal Academy of Engineering and the Royal Society. The Royal Society.

Barfield, W., \& Williams, A. (2017). Cyborgs and enhancement technology. Philosophies, 2, 4. https:// doi.org/10.3390/philosophies2010004

Barreto, P. S., Ferrandes, A. M., \& Gulihard-Costa, A. M. (2011). Predictors of body satisfaction: 
Differences between older men and women's perceptions of their body functioning and appearance. Journal of Aging and Health, 23, 505-528. https://doi.org/10.1177/0898264310386370

Bates, T. J., Fergason, J. R., \& Pierrie, S. N. (2020). Technological advances in prosthesis design and rehabilitation following upper extremity limb loss. Current Reviews in Musculoskeletal Medicine, 13, 485-493. https://doi.org/10.1007/s12178-02009656-6

Blodgett-Ford, S. J. (2021). Human enhancements and voting: Towards a declaration of rights and responsibilities of beings. Philosophies, 6, 5. https:// doi.org/10.3390/philosophies6010005

Bostrom, N. (2005). Transhumanist values. Journal of Philosophical Research, 30, 3-14. https://doi.org/ 10.5840/jpr_2005_26

Bostrom, N., \& Sandberg, A. (2009). Cognitive enhancement: Methods, ethics, regulatory challenges. Science and Engineering Ethics, 15, 311-341. https://doi.org/10.1007/s119-4-8-0099142-5

Chadwick, R. (2008). Therapy, enhancement and improvement. In B. Gordijn \& R. Chadwick (Eds.), Medical enhancement and posthumanity. The international library of ethics, law and technology (Vol. 2, pp. 25-37). Springer.

Cieciuch, J., Davidov, E., Vecchione, M., Beierlein, C., \& Schwartz, S. H. (2014). The cross-national invariance properties of a new scale to measure 19 basic human values: a test across eight countries. Journal of Cross-Cultural Psychology, 45, 764-776. https://doi.org/10.1177/0022022114527348

Cieciuch, J., \& Schwartz, S. H. (2018). Pomiar wartości w kołowym modelu Schwartza [Measurement of values in the Schwartz circular model]. In H. Gasiul (Ed.), Metody badania emocji i motywacji [Methods of studying emotions and motivation] (pp. 307-334). Warszawa: Difin.

Daniels, N. (2000). Normal functioning and the treatment enhancement distinction. Cambridge Quarterly of Health Care Ethics, 9, 309-322. https://doi. org/10.1017/S0963180100903037

Coenen, C., Schuijff, M., Smits, M., \& Hennen, L. (2008). Shifting boundaries, changing concepts, and the governance of human enhancement (Results of two expert meetings). Deliverable no. 2 of the project "Human Enhancement". European Technology Assessment Group.

Erler, A. (2017). The limits of the treatment-enhancement distinction as a guide to public policy. Bioethics, 31, 608-615. https://doi.org/10.1111/bioe. 12377

Fahn, C. W. (2020). Marketing the prosthesis: Supercrip and superhuman narratives in contemporary cultural representations. Philosophies, 5, 11. https://doi.org/10.3390/philosophies5030011

Górnik-Durose, M., Jach, Ł., Pasztak-Opiłka, A., \& Sikora, T. (2020). Sens i wartość zdrowia w kontekście wspótczesnej mentalności [The meaning and value of health in the context of contemporary mentality]. Difin.

Gurtner, D. (2021). Neuralink and beyond: Challenges of creating an enhanced human. University of Fribourg.

Haidt, J., \& Joseph, C. (2007). The moral mind: How five sets of innate intuitions guide the development of many culture-specific virtues, and perhaps even modules. In P. Carruthers, S. Laurence, \& S. Stitch (Eds.), The innate mind (Vol. 3, pp. 371396). Oxford University Press.

Harati, Y. N. (2015). Sapiens: a brief history of humankind. Harper.

Harari, Y. N. (2017). Homo Deus. a brief history of tomorrow. Harper.

Jach, Ł. (2019). Spotlight on scientotheism. Structure and psychometric properties of the questionnaire for the study of scientistic worldview aspects. The Review of Psychology, 62, 141-165.

Jach, Ł. (2020). Światopogląd scjentystyczny - korelaty i uwarunkowania [Scientistic worldview - correlates and conditions]. Wydawnictwo Uniwersytetu Śląskiego.

Jach, Ł. (2021). How to distinguish a "scientoskeptic" from a "scientoenthusiast"? Psychometric properties and criteria for qualitative interpretation of the scores of the Views of Science Questionnaire in a Polish quota sample. Current Issues in Personality Psychology, 9, 66-83. https://doi.org/10.5114/ cipp.2021.104596

Jach, Ł., \& Buczek, A. (2021). Who says "yes" to science without ethics? Acceptance of the violation of ethical norms due to scientific reasons in the context of empathy, systemizing, and the scientistic worldview. Personality and Individual Differences, 179, 110950. https://doi.org/10.1016/j.paid. 2021.110950

Jach, Ł., \& Chmiel, S. (2018). The reliability of advertising, the rule of social proof and the rule of scientific authority. Polish Journal of Economic Psychology, 13, 19-34. https://doi.org/10.15678/PJOEP. 2018.13.12

Jensen, S. R., Nagel, S., Brey, P., Kuldek, K., Ditzel, T., Oluoch, I., Zuiderdiun, A. C., \& Wagner, N. F. (2020). SIENNA D3.4: Ethical analysis of human enhancement technologies. Zenodo. https://doi.org/ 10.5281/zenodo.4068071

Jotterand, F. (2010). Human dignity and transhumanism: Do anthro-technological devices have moral status? American Journal of Bioethics, 10, 45-52. https://doi.org/10.1080/15265161003728795

Karaś, D., \& Cieciuch, J. (2017). Polish adaptation of Carol Ryff's psychological wellbeing scales. Annals of Psychology, 20, 837-853. https://doi.org/ 10.18290/rpsych.2017.20.4-4en

Klichowski, M. (2015). Transhumanism and the idea of education in the world of cyborgs. In H. KrauzeSikorska \& M. Klichowski (Eds.), The educational 
and social world of a child. Discourses of communication, subjectivity and cyborgization (pp. 431-438). Adam Mickiewicz University Press.

Kurzweil, R. (2006). Singularity is near. Penguin Books.

Latheef, S., \& Henschke, A. (2020). Can a soldier say no to an enhancing intervention? Philosophies, 5, 13. https://doi.org/10.3390/philosophies5030013

Lilley, S. (2013). Transhumanism and society. The social debate over human enhancement. Springer.

Musk, E., \& Neuralink (2019). An integrated brainmachine interface platform with thousands of channels. Journal of Medical Internet Research, 21, e16194. https://doi.org/10.2196/16194

Nakar, S., Weinberger, S., \& Greenbaum, D. (2015). Legal and social implications of predictive brain machine interfaces: Duty of care, negligence, and criminal responsibility. AJOB Neuroscience, 6, 40-42. https://doi.org/10.1080/21507740.2015.1094558

Pirmagomedov, R., \& Koucheryavy, Y. (2019). loT technologies for augmented human: a survey. Internet of Things, 14, 100120. https://doi.org/10.1016/j.iot. 2019.100120

Prudhomme, M., Nagel, S., Jensen, S., Hanson, T., Greene, O., \& Spedding, G. (2020). SIENNA D3.5: Public views of human enhancement technologies in 11 EU and non-EU countries. Zenodo. https://doi. org/10.5281/zenodo.4068194

Ryff, C. D. (1989). Happiness is everything, or is it? Explorations on the meaning of psychological wellbeing. Journal of Personality and Social Psychology, 57, 1069-1081. https://doi.org/10.1037/00223514.57.6.1069

Schelle, K. J., Faulmüller, N., Caviola, L., \& Hewstone, M. (2014). Attitudes toward pharmacological cognitive enhancement - a review. Frontiers in Systems Neuroscience, 8, 53. https://doi.org/10.3389/ fnsys.2014.00053

Schwartz, S. H. (1992). Universals in the content and structure of values: Theory and empirical tests in 20 countries. In M. Zanna (Ed.), Advances in experimental social psychology (Vol. 25, pp. 1-65). Academic Press.

Schwartz, S. H., Cieciuch, J., Vecchione, M., Torres, C., Dirilen-Gumus, O., \& Butenko, T. (2017). Value tradeoffs propel and inhibit behavior: Validating the 19 refined values in four countries. European Journal of Social Psychology, 47, 241- 258. https:// doi.org/10.1002/ejsp.2228

Tegmark, M. (2017). Life 3.0: Being human in the age of artificial intelligence. Penguin Books.

Tillson, J., \& Aldridge, D. (2018). Cheating education: Is technological human enhancement the new frontier of learning? Educational Theory, 68, 589-594. https://doi.org/10.1111/edth. 12341
Whetstine, L. M. (2015). Cognitive enhancement: Treating or cheating? Seminars in Pediatric Neurology, 22, 172-176. https://doi.org/10.1016/j.spen. 2015.05.003

Whitman, D., Love, J., Rainville, G., \& Skufca, L. (2018). U.S. public opinion and interest on human enhancements technology. AARP Research. https:// doi.org/10.26419/res.00192.001 


\section{Appendix A}

\section{TECHNOLOGICAL ENHANCEMENTS QUESTIONNAIRE - LIST OF ITEMS}

(ENGLish translation; FOR THE POLISH Version, PLEASE CONTACT THE CORRESPONDING AUthor)

1. Human enhancement technologies are a threat. (item with reversed scoring)

2. Human enhancement technologies will bring more benefits than harm.

3. Human enhancement technologies should be developed.

4. The use of human enhancement technologies is an appropriate direction of human species development.

5. Human enhancement technologies should only be used to compensate for deficits, e.g., to help people with disabilities. (item with reversed scoring)

6. I would like to use human enhancement technologies.

7. People should be able to freely replace body parts with products resulting from development of human enhancement technologies.

8. There is no need to develop human enhancement technologies as the already existing solutions are sufficient. (item with reversed scoring)

9. The use of human enhancement technologies raises serious ethical questions. (item with reversed scoring)

10. Society will benefit significantly from having technologically improved people in it.

11. Human enhancement technologies will significantly improve the quality of life of people with diseases and disabilities.

12. The use of human enhancement technologies will lead to negative social changes. (item with reversed scoring)

13. I would not like to live in a world with developed human enhancement technologies. (item with reversed scoring)

14. I am pleased with the prospect of developing human enhancement technologies.

Possible answers in every item: 1 - definitely disagree, 2 - mostly disagree, 3 - partially agree and partially disagree, 4 - mostly agree, 5 - definitely agree 


\section{Appendix B}

\section{VERSIONS OF HUMANISM QUESTIONNAIRE \\ (English translation; FOR the Polish Version, Please contact the CORResponding aUthor)}

This questionnaire measures attitudes to different versions of humanism. Read the following statements carefully, marking in each case one answer that best fits your beliefs. If, in any case, you agree with several statements, choose the one you consider the most appropriate.

1. The school teacher should:

a) give the same amount of attention to each student $(\mathrm{L})$

b) pay special attention to gifted students $(E)$

c) treat the class as a group whose members work together and achieve common goals (S)

2. First of all, the state should:

a) support people with particularly desirable traits $(\mathrm{E})$

b) to support all citizens socially (S)

c) support each citizen in activities that best suit their preferences (L)

3. When working in a group, the most important is:

a) listening to each member of the team (L)

b) choosing a leader and dividing tasks according to predispositions (E)

c) focusing the team on the goal and complying with it (S)

4. In society:

a) each person is equally important and unique (L)

b) every person is a part that should work for the whole (S)

c) some outstanding individuals are more important than others $(\mathrm{E})$

5. When making decisions, one should be guided mainly by:

a) one's preferences ( $L$ )

b) usefulness to others $(\mathrm{S})$

c) personal predispositions (E)

6. Human personality:

a) is shaped primarily by education and environmental influences (S)

b) is shaped primarily by biological predispositions (E)

c) is unique and shaped in a way that is unique for everyone (L)

7. The world should be discovered:

a) through individual experience and reflection $(\mathrm{L})$

b) through the work of organized, collective institutions (S)

c) through the experience of individuals or groups objectively better than others $(E)$

8. The development of humanity should take place at:

a) the individual level - one should develop for oneself ( $L$ )

b) the social level - it is necessary to associate into well-functioning systems that work for the common good (S)

c) the species - humanity should evolve, and better individuals and groups should displace the weaker (E)

9. War:
a) brings collective benefits, such as overthrowing regimes $(\mathrm{S})$
b) provides an opportunity to strengthen the most desirable human qualities (E)
c) is unquestionably wrong because individuals suffer because of it (L)

10. The best art is that which:
a) best suits personal tastes (L)
b) best supports the development of society as a whole (S)
c) fits best with the objective esthetic criteria (E)

11. Peace in the world could come about through:
a) respecting the diversity of all nations and cultures of the world ( $L$ )
b) recognition of the equality and unity of all peoples and cultures of the world (S)
c) the development of humanity and the emergence of a morally better species (E)

12. The law should:

a) provide further freedom to outstanding individuals whose actions improve the general condition of humanity (E)

b) treat all units the same $(\mathrm{L})$

c) be created taking into account the needs of social groups and society as a whole (S) 
13. Political choices should be made by:
a) all citizens ( $\mathrm{L})$
b) political parties $(\mathrm{S})$
c) outstanding individuals, e.g., the most intelligent (E)

14. Standards of behavior should be established following:
a) personal preferences (L)
b) social conventions $(\mathrm{S})$
c) human biological nature $(\mathrm{E})$

15. People with disabilities:
a) are a burden on other people (E)
b) have their personal value (L)
c) should be provided community care $(\mathrm{S})$

16. In fact, human choices are:
a) made freely because people have free will (L)
b) determined by biological factors (E)
c) dependent on social conditions (S)

17. Physical attractiveness:
a) should not affect the individual's position in society $(\mathrm{S})$
b) cannot be judged objectively, as everyone can be attractive in their own way (L)
c) can be an indicator of human quality $(E)$

18. Political correctness:
a) is reasonable - everyone is unique and therefore deserves respect ( $L$ )
b) is justified - failure to apply it could lead to the disintegration of human communities (S)
c) is redundant - some people and groups are objectively better or worse (E)

19. The most important is:
a) the benefit of the individual (L)
b) the benefit of society (S)
c) the benefit of the human species $(\mathrm{E})$

20. The state should be governed by:
a) people with the highest intellectual competencies $(\mathrm{L})$
b) people with the best understanding of the public interest (S)
c) persons elected by popular vote $(\mathrm{E})$

21. The following people should be recruited to the army:
a) all people of appropriate age (S)
b) only people with specific predispositions (E)
c) only people willing to serve in the army (L)

22. Medicines:
a) should be refunded equally for all citizens (L)
b) should be refunded according to the level of wealth (S)
c) should not be refunded in any way $(E)$

23. In society, access to material goods and certain goods should be granted according to personal:
a) needs (L)
b) contributions $(\mathrm{S})$
c) material resources $(\mathrm{L})$

24. The admission system for studies should support in particular:
a) people with the strongest predispositions (E)
b) the most impoverished people (S)
c) everyone following their interests (L)

25. The purpose of sports competitions is:
a) entertainment and the opportunity to pursue one's passion (L)
b) testing and honoring the most skillful people (E)
c) giving people a sense of community $(\mathrm{S})$

The greater the number of selected (L), (S), or (E) responses, the higher the level of the liberal, social, or evolutionary version of humanism. 


\section{Appendix C}

\section{Table A}

Frequencies of each response and the item-scale correlation coefficients in the Technological Enhancements Questionnaire

\begin{tabular}{|c|c|c|c|c|c|c|c|}
\hline Item & $\begin{array}{c}\text { Definitely } \\
\text { disagree }\end{array}$ & $\begin{array}{c}\text { Mostly } \\
\text { disagree }\end{array}$ & $\begin{array}{l}\text { Partially } \\
\text { agree and } \\
\text { partially } \\
\text { disagree }\end{array}$ & $\begin{array}{c}\text { Mostly } \\
\text { agree }\end{array}$ & $\begin{array}{c}\text { Definitely } \\
\text { agree }\end{array}$ & $\begin{array}{c}\text { Item-scale } \\
\text { correlation } \\
\text { coefficient } \\
\text { (after reverse } \\
\text { scoring) }\end{array}$ & $\begin{array}{c}\text { Cronbach's } \alpha \\
\text { if item } \\
\text { dropped }\end{array}$ \\
\hline 1 (reversed) & 19 & 42 & 56 & 18 & 4 & .60 & .91 \\
\hline 2 & 6 & 22 & 40 & 51 & 20 & .45 & .92 \\
\hline 3 & 1 & 4 & 20 & 61 & 53 & .72 & .91 \\
\hline 4 & 8 & 17 & 36 & 47 & 31 & .81 & .90 \\
\hline 5 (reversed) & 17 & 34 & 26 & 39 & 23 & .58 & .91 \\
\hline 6 & 16 & 34 & 28 & 39 & 22 & .67 & .91 \\
\hline 7 & 25 & 21 & 37 & 29 & 27 & .63 & .91 \\
\hline 8 (reversed) & 63 & 52 & 51 & 3 & 0 & .51 & .91 \\
\hline 9 (reversed) & 20 & 37 & 38 & 26 & 18 & .59 & .91 \\
\hline 10 & 11 & 14 & 35 & 51 & 28 & .68 & .91 \\
\hline 11 & 0 & 2 & 6 & 49 & 82 & .42 & .92 \\
\hline 12 (reversed) & 16 & 46 & 47 & 22 & 8 & .66 & .91 \\
\hline 13 (reversed) & 37 & 49 & 34 & 15 & 4 & .75 & .90 \\
\hline 14 & 3 & 10 & 41 & 51 & 34 & .81 & .90 \\
\hline
\end{tabular}

